\title{
Padaczka- choroba społeczna XXI wieku
}

\author{
Epilepsy- the Social Disease of the $21^{\text {st }}$ Century
}

\section{Streszczenie}

Padaczka uznawana jest za jedną z najstarszych znanych pierwotnych chorób neurologicznych. Wiodącym jej elementem są powtarzalne incydenty występowania nagłych zaburzeń elektrochemicznych określonych komórek nerwowych $\mathrm{w}$ mózgu. Charakteryzuje się ją także nieodłącznie $\mathrm{z}$ napadem drgawkowym oraz z wysokim ryzykiem nawrotu napadu. Padaczka dotyczy około 50 milionów pacjentów na całym świecie. Stanowi ona niejednorodną grupę zaburzeń, dlatego też zebranie dokładnych danych epidemiologicznych bywa trudne. W Polsce szacuje się, że blisko 300-400 tyś. osób cierpi na tą jednostkę chorobową. Wiodącą rolą stosowanych leków przeciwpadaczkowych jest hamowanie drgawek oraz kontrola ich napadów. Głównym kryterium charakteryzującym te leki jest podnoszenie progu drgawkowego. Wybór środków farmakologicznych jest zależny od typu napadów i zespołów padaczkowych. U osób z padaczką czasami dochodzi do występowania nagłej niespodziewanej śmierci (SUDEP).

\begin{abstract}
:
Epilepsy is considered one of the oldest known original neurological diseases, and its most characteristic feature are repeated incidents of sudden disorders of electrochemical nerve cells in the brain. Inherently, it is also related to seizures and high risk of the reoccurrence of the seizure. Epilepsy affects about 50 million patients worldwide. It is a heterogeneous group of disorders, thus collecting any accurate epidemiological data may come as a great difficulty. It is estimated that nearly 300-400 thousand people suffer from this disease. The most significant role ascribed to antiepileptic drugs is the inhibition of seizures and control of seizures. The main criterion for characterizing these drugs is increasing the threshold for seizures. The choice of pharmaceuticals is preconditioned by the type of seizures and epileptic syndromes. In case of people with epilepsy the prevalence of sudden unexpected death (SUDEP)may sometimes occur.
\end{abstract}

Słowa kluczowe: padaczka, nagła niespodziewana śmierć, choroba społeczna. Key words: epilepsy, sudden unexpected death, social disease.

\section{Wstęp}

Padaczka uznawana jest za jedną $\mathrm{z}$ najstarszych znanych chorób neurologicznych. Charakteryzowana jest jako pierwotna choroba mózgu. Jej wiodącą istotą jest występowanie nagłych zaburzeń elektrochemicznych określonych komórek nerwowych w mózgu. Schorzenie to dotyczy około 50 milionów pacjentów na całym świecie [1]. Chorzy na padaczkę zmuszeni są do radzenia sobie $\mathrm{z}$ wieloma problemami kreowanymi przez to schorzenie. $\mathrm{W}$ konsekwencji 
doprowadza to do znacznego obniżenia ich jakości życia. W badaniach przeprowadzonych przez Sorge i wsp. [2] wykazano, iż rozpowszechnienie depresji wśród osób z padaczką wynosi 14,8\%. W badaniach przeprowadzonych przez Espinosa i wsp. [3] wśród osób chorych na epilepsję również odnotowano znaczny spadek jakości życia. Wynika ona głównie z współwystępowania z padaczką depresji oraz $\mathrm{z}$ senności $\mathrm{w}$ ciągu dnia. Chorym często towarzyszy lęk przed napadami. Ograniczają oni życie towarzyskie oraz borykają się z problemami na tle społecznym, jak np. praca, rodzina, sytuacja materialna. Czują się bezsilni i ograniczeni we własnym ciele. Niezwykle istotna, w dobie zwiększającej się ilości zachorowań na padaczkę, staje się edukacja społeczeństwa na temat tego schorzenia [4].

\section{Definicja i postacie choroby}

Padaczka definiowana jest jako zespół objawów, ściśle związanych z zaburzeniami czynnościowymi mózgu. Wiodącym jej elementem są powtarzalne incydenty objawów często powiązanych z utratą lub zaburzeniami świadomości. Charakteryzuje się ją także nieodłącznie z napadem drgawkowym oraz z wysokim ryzykiem nawrotu napadu (czyli 60\% lub większe prawdopodobieństwo) [5]. Uważana jest za jedną $\mathrm{z}$ najstarszych poznanych chorób przewlekłych. Występuje ona $\mathrm{w}$ formie licznych postaci klinicznych, dlatego często stanowi problem diagnostyczny [6]. Napad padaczkowy z kolei definiowany jest jako przemijające zaburzenie fizjologiczne mózgu, pojawiające się z powodu wzmożonych wyładowań skupisk komórek nerwowych. $\mathrm{W}$ trakcie jego trwania pojawiają się objawy wegetatywne, somatyczne oraz psychiczne lub połączenie w/w objawów [7]. Komisja ds. Klasyfikacji i Terminologii Międzynarodowej Ligi Przeciwpadaczkowej zaproponowała podział etiologiczny obejmujący trzy podtypy: metaboliczne, genetyczne oraz o nieznanej etiologii. Podtypy te dotyczą zarówno zespołów w których występują napady częściowe, uogólnione jak i o symptomatologii mieszanej. Wśród napadów uogólnionych wyróżniamy: napady nieświadomości, miokloniczne, atoniczne, toniczno-kloniczne, toniczne i kloniczne, pierwotne uogólnione, wtórnie uogólnione. Napady częściowe zaś dzielimy na proste, z objawami ruchowymi, z objawami czuciowymi lub zmysłowymi, z objawami autonomicznymi, z objawami psychicznymi oraz napady złożone [8]. Jednym $\mathrm{z}$ podstawowych kryteriów służących do rozpoznania padaczki jest wystąpienie przynajmniej dwóch napadów [9]. W diagnostyce tego schorzenia konieczne jest zatem przeprowadzenie dokładnego wywiadu, badań biochemicznych, neuropsychiatrycznych oraz badań obrazowych. Niezbędne jest także przeprowadzenie elektroencefalografii (EEG). Obecność wykrytych zmian napadowych w EEG koreluje ze wzmożoną powtarzalnością napadów [10]. W badaniu przeprowadzonym przez Leitinger i wsp. [11] wśród 220 pacjentów uznano badanie EEG za wysoko dokładną metodę diagnostyczną. Wprowadzane nowoczesne metody i postęp technologii nie pozwalają jeszcze na rozpoznanie etiologii padaczki. U blisko 65$75 \%$ chorych etiologia tego schorzenia pozostaje nieznana [12]. W znacznej części przyjmuje się, iż główną przyczyną padaczki są zmiany naczyniopochodne w mózgu. Zmiany te w głównej mierze dotyczą osób w podeszłym wieku. Za pozostałe czynniki wpływające na występowanie napadów padaczkowym uznaje się choroby zwyrodnieniowe mózgu, guzy mózgu, przebyte urazy głowy oraz zakażenia ośrodkowego układu nerwowego. Szacuje się, iż za blisko 1,5\% przyczyn padaczki odpowiadają czynniki toksyczne takie jak np. alkohol oraz niektóre zaburzenia metaboliczne np. mocznica $[9,13]$.

\section{Epidemiologia}

Padaczka dotyczy około 50 milionów pacjentów na całym świecie. Stanowi ona niejednorodną grupę zaburzeń, dlatego też zebranie dokładnych danych epidemiologicznych bywa trudne. 
Aktualne systemy klasyfikacji oraz diagnostyka uzależnione są od lokalnych zwyczajów i kultury [14]. Niedostateczna liczba badań epidemiologicznych wynika głównie też z faktu prowadzenia badań wśród małych grup populacyjnych. Według wielu autorów częstość występowania padaczki wynosi od 9,9 do 41/100 000 na rok. Największa liczba zachorowań odnotowywana jest wśród dzieci oraz osób w podeszłym wieku [15]. Rozpowszechnienie padaczki opisuje się na poziomie 1000/100 000 osób. Przyjmuje się, że padaczka występuje u około 1\% populacji. W Polsce szacuje się, że blisko 300-400 tyś. osób cierpi na tą jednostkę chorobową [16]. Podane dane nie odzwierciedlają skali problemu, ponieważ nie odnoszą się do jednego napadu padaczkowego, który często występuję w okresie całego życia [17].

\section{Leczenie}

Wiodącą rolą stosowanych leków przeciwpadaczkowych jest hamowanie drgawek oraz kontrola ich napadów. Głównym kryterium charakteryzującym te leki jest podnoszenie progu drgawkowego [18]. Wybór środków farmakologicznych jest zależny od typu napadów i zespołów padaczkowych [19]. Obecnie do najczęściej zażywanych leków przeciwpadaczkowych (LPP) zaliczamy: kwas walproinowy (VPA), karbamazepinę (CBZ), fenobarbital (PB), fenytoinę (DPH) oraz leki z grupy benzodwuazepiny [20]. W leczeniu padaczki dużą uwagę poświęca się zwłaszcza osobom starszym W związku ze zmianami obserwowanymi w strukturze demograficznej społeczeństwa liczba pacjentów powyżej 65 rż. progresywnie wzrasta. Statystycznie wzrasta również liczba osób z rozpoznaną padaczką. U osób starszych drgawki występują $\mathrm{z}$ nietypowymi objawami, co powoduje, że postawienie prawidłowej diagnozy staje się coraz trudniejszym wyzwaniem. U pacjentów $\mathrm{w}$ podeszłym wieku mogą wystąpić wzmożone działania niepożądane leków przeciwpadaczkowych w porównaniu z chorymi młodszych kategorii wiekowych. U seniorów często także obserwowane jest zjawisko polipragmazji. Dochodzi też do interakcji między zażywanymi lekami i wówczas prowadzi to do zahamowania działań stosowanych preparatów [21]. W badaniach przeprowadzonych przez Brunn i wsp. [22] wśród 529 pacjentów w wieku 65 lat i powyżej oceniono skuteczność wstępnego leczenia przeciwpadaczkowego (AED) w monoterapii z nowo rozpoznaną padaczką. Zauważono, iż rokowanie występowania napadów padaczki jest dobre, a większość pacjentów może być skutecznie leczona już przy pierwszym zastosowaniu AED. Oszacowano, iż prawdopodobieństwo wystąpienia remisji $\geq 2$ lat wynosi $83 \%$, natomiast $\geq 5$ już $79 \%$. Aktualne prowadzone są również badania nad nową formą leczenia tego schorzenia poprzez stosowanie przezczaszkowej stymulacji magnetycznej (TMS). Metoda ta polega na pobudzaniu bądź zahamowaniu neuronów, poprzez wytwarzanie powtarzających się impulsów o niskiej częstotliwości. Działanie to opiera się na prawie indukcji elektromagnetycznej. Prowadzone badania wykazuję istotnie statystycznie zmniejszenie częstości napadów o ok. 72-78,9\%. Nadal kontynuowane są badania oceniające skuteczność tej metody i uzyskiwanych przez nią wyników [23]. W leczeniu padaczki zespół terapeutyczny często boryka się $\mathrm{z}$ problemem nie przestrzegania zaleceń lekarskich i nie przyjmowania regularnie przepisanych leków przez pacjentów. Takie postępowanie stanowi wyzwanie dla pomyślnego procesu leczenia padaczki. Wiele przeprowadzonych badań wykazało, że regularne przyjmowanie leków przeciwpadaczkowych znacznie zmniejsza częstość występowania napadów i pozwala na ich kontrolę [24].

\section{Nagła niespodziewana śmierć $w$ padaczce}

Nagła niespodziewana śmierć w padaczce (SUDEP) opisywana jest jako niespodziewana i nagła, niepowiązana z żadnym urazem śmierć u chorych na padaczkę, u których przeprowadzona 
sekcja zwłok nie stwierdziła toksykologicznych i organicznych przyczyn zgonu [25]. Częstość jej występowania szacuje się na blisko 9/1000 pacjentów [26]. Inne prowadzone badania wykazują częstotliwość SUDEP na poziomie 0,35 przypadków/1000 osób. U pacjentów z przewlekłą padaczką częstość występowania SUDEP jest znacznie większa i wynosi około 1-2/1000 osób, natomiast u osób z ciężkimi napadami szacuje się na blisko 3-9/1000 osób. Najwyższe wskaźniki liczebności SUDEP wskazują na wzmożoną częstość występowania tego zjawiska wśród chorych między 20 a 40 rż. [27]. W badaniu przeprowadzonym przez Zhanga i wsp. [28] wyróżniono trzy główne prawdopodobne czynniki ryzyka SUDEP tj. wczesny wiek występowania drgawek, wysoka częstość występowania drgawek przed rozpoczęciem regularnego leczenia oraz doświadczenie jednego lub więcej napadu padaczkowego $\mathrm{w}$ ciągu miesiąca. Nagła niespodziewana śmierć w padaczce występuje statystycznie częściej u pacjentów z napadami tonicznio-klonicznymi [27]. Według wielu badań istotnym aspektem $\mathrm{w}$ zapobieganiu SUDEP staje się nocna kontrolna stanu zdrowia chorego na padaczkę oraz eliminowanie samotności. W metaanalizie przeprowadzonej przez Maquire i wsp. [29] również zwrócono uwagę na konieczność nocnego nadzoru chorego na padaczkę. Chociaż występowanie SUDEP ma pewne czynniki ryzyka jest nieoczekiwanym i bardzo traumatycznym wydarzeniem. Ciągle brakuje skutecznych metod zapobiegania. W związku z tym warto zwrócić uwagę na modyfikowalne czynniki ryzyka oraz edukację chorych i ich rodzin. Należy zwiększać świadomość społeczeństwa na temat możliwości wystąpienia SUDEP nawet $\mathrm{w}$ najmniej oczekiwanym momencie [30]. W badaniu przeprowadzonym przez Ramachandran Nair i wsp. [31] wśród 27 osób pogrążonych w żałobie z powodu śmierci krewnego (rodzica, rodzeństwa, małżonka lub dziecka) w wyniku SUDEP prawie wszyscy respondenci wskazali na konieczność prowadzenia dyskusji na temat SUDEP. Badani zwrócili uwagę na częsty brak informacji ze strony personelu medycznego na temat możliwości wystąpienia SUDEP. Przy omawianiu tego zjawiska, według respondentów należy zwrócić uwagę na czynniki ryzyka, możliwość stosowania strategii zapobiegawczych oraz na rzadkość występowania tego śmiertelnego incydentu. SUDEP jest trudnym tematem dla personelu medycznego i wyraźnie jeszcze większą barierą, aby omówić go z pacjentami i ich opiekunami. Istotna staje się także optymalizacja leczenia padaczki, która prawdopodobnie może uniemożliwić niektóre ze zgonów SUDEP [32]. Konieczne są dalsze badania nad występowaniem tego zjawiska wśród chorych [27].

\section{Wnioski}

1. Padaczka należy do najczęstszych chorób neurologicznych występujących wśród społeczeństwa i dotyka blisko 1\% Polaków.

2. Farmakoterapia tego schorzenia jest wieloletnim i skomplikowanym procesem. Stanowi wyzwanie zwłaszcza wśród osób w podeszłym wieku, u których występują inne choroby współistniejące oraz wielolekowość.

3. U osób z padaczką czasami dochodzi do występowania nagłej niespodziewanej śmierci (SUDEP). Chociaż jego wystąpienie często wiążę się z pewnymi czynnikami ryzyka, jest wydarzeniem nieoczekiwanym i traumatycznym.

4. Istnieje konieczność potrzeby zwiększania wiedzy i świadomości na temat epilepsji oraz możliwości wystąpienia w jej przebiegu nagłej niespodziewanej śmierci. 


\section{Bibliografia/Bibliography:}

1. Ernst L.D., Boudreau E.A. Recent advances in epilepsy management. Curr Opin Anaesthesiol. 2016;29(5):558-566.

2. Sorge S.T., Hesdorffer D.C., Phelan J.C. Depression and genetic causal attribution of epilepsy in multiplex epilepsy families. Epilepsia.2016 Aug 25. doi: 10.1111/epi.13500.

3. Espinosa Jovel C.A., Ramírez Salazar S., Rincón Rodríguez C., Sobrino Mejia F.E. Factors associated with quality of life in a low-income population with epilepsy. Epilepsy_Res. 2016;127:168-174.

4. McCagh J., Fisk J.E., Baker G.A. Epilepsy, psychosocial and cognitive functioning. Epilepsy Research. 2009;86:1-14.

5. St Louis E.K., Cascino G.D. Diagnosis of Epilepsy and Related Episodic Disorders. Continuum (Minneap Minn). 2016;22:15-37.

6. Piazzini A., Canevini M.P., Maggiori G., Canger R. The perceptron of memory failures in patients with epilepsy. Eur J Neurol. 2001;8:613.20.

7. Pittau F., Korff C.M., Nordli D.R. Jr. Epileptic spasms in epilepsy with myoclonic-atonic seizures (Doose syndrome). Epileptic Disord. 2016;18(3):289-96.

8. Berg A.T., Berkovic S.F., Brodie M.J., i wsp. Revised terminology and concepts for organization of seizures and epilepsies: report of the ILAE Commission on Classification and Terminology, 2005-2009. Epilepsia. 2010;51:676-685.

9. Jędrzejczak J. Padaczka. W: Kozubski W., Liberski P.P (red.). Nerologia. Warszawa 2004.

10. Sirven J.I. Antiepileptic drug therapy for adults: when to initiate and how to choose. Mayo Clin Proc. 2002;77:1367-1375.

11. Leitinger M., Trinka E., Gardella E., i wsp. Diagnostic accuracy of the Salzburg EEG criteria for non-convulsive status epilepticus: a retrospective study. Lancet Neurol. 2016;15(10):1054-62.

12. Hauser A.W., Annegers J.F., Kurland L.T.: Incidence of epilepsy and unprovoked seizures in Rochester, Minnesota:1935-1984. Epilepsia. 1993;34(3):453-468.

13. Glauser T., Ben-Menachem E., Bourgeois B. i wsp. ILAE treatment guidelines: evidencebased analysis of antiepileptic drug efficacy and effectiveness as initial monotherapy for epileptic seizures and syndromes. Epilepsia. 2006;47:1094-1120.

14. Behr C., Goltzene M.A., Kosmalski G., Hirsch $\quad$ E. Ryvlin $\quad$ PRev Neurol (Paris). Epidemiology of epilepsy.2016;172(1):27-36. 
15. Sánchez S., Rincon F. Status Epilepticus: Epidemiology and Public Health Needs. J Clin Med. 2016;5(8). pii: E71. doi: 10.3390/jcm5080071.

16. Jędrzejczak J. Padaczka. BNP. Lublin 200.6

17. Panayiotopoulos C.P. A clinical guide to epileptic syndromes and their treatment. Springer Healthcare LTD, 2010.

18. Mutschler E., Geisslinger G., Kroemer H.K., i wsp. Mutschler Farmakologia i Toksykologia. Wydawnictwo Medyczne Urban \& Partner, Wrocław 2004.

19. Wallace S.J. Epilepsy in cerebral palsy. Developmental Medicine J. Child Neurology. 2001:43:713-717.

20. Jędrzejczak J., Zwoliński P. Nowe leki przeciwpadaczkowe. Fundacja Epileptologii. Warszawa 2000.

21. Motika P.V., Spencer D.C. Treatment of Epilepsy in the Elderly. Curr Neurol Neurosci Rep. 2016;16(11):96.

22. Bruun E., Kälviäinen R., Keränen T. Outcome of initial antiepileptic drug treatment in elderly patients with newly diagnosed epilepsy. Epilepsy_Res. 2016;127:60-65.

23. Chen R., Spencer D.C., Weston J., i wsp. Transcranial magnetic stimulation for the treatment of epilepsy. Cochrane Database Syst Rev.2016;(8):CD011025. doi: 10.1002/14651858.CD011025.pub2.

24. da Mota Gomes M., Navarro T., Keepanasseril A., i wsp. Increasing adherence to treatment in epilepsy: what do the strongest trials show? Acta Neurol Scand. 2016 doi: 10.1111/ane.12668.

25. Maguire M.J., Jackson C.F., Marson A.G., i wsp. Treatments for the prevention of Sudden Unexpected Death in Epilepsy (SUDEP). Cochrane Database Syst Rev. 2016;7:CD011792. doi: 10.1002/14651858.CD011792.pub2.

26. Surges R., Sander J.W. Sudden unexpected death in epilepsy: mechanisms, prevalence, and prevention. Curr Opin Neurol. 2012;25(2):201-7.

27. Tomson T., Walczak T., Sillanpaa M., i wsp. Sudden unexpected death in epilepsy: a review of incidence and risk factors. Epilepsia. 2005;46(11):54-61.

28. Zhang W.W., Si Y., Chen T., i wsp. Risks of probable SUDEP among people with convulsive epilepsy in rural West China. Seizure. 2016;39:19-23.

29. Maguire M.J., Jackson C.F., Marson A.G., Nolan S.J. Treatments for the prevention of Sudden Unexpected Death in Epilepsy (SUDEP). Cochrane Database Syst Rev. 2016;7:CD011792. doi: 10.1002/14651858.CD011792.pub2. 
30. Marin Collazo I.V., Tatum W.O. Sudden Unexpected Death in Epilepsy (SUDEP): Are All Your Patients Informed? Neurologist. 2016;21(4):66-71.

31. Ramachandran Nair R., Jack S.M., Strohm S. SUDEP: To discuss or not? Recommendations from bereaved relatives. Epilepsy Behav. 2016;56:20-5.

32. Aurlien D., Olsen T.R., Taubøll E. Sudden unexpected death in epilepsy (SUDEP). Tidsskr Nor Laegeforen. 2016;136(2):131-5. 